\title{
Pipette Closure Device
}

National Cancer Institute

\section{Source}

National Cancer Institute. Pipette Closure Device. NCI Thesaurus. Code C154642.

Closure with pipette. 